\title{
Association between smoking and hearing status: a comparative study between smokers and non - smokers
}

\author{
Waseem S.M. $A^{1 *}$, Kumari $A^{2}$, Misra $S^{3}$, Singh $C^{4 *}$, Singh $S^{5 *}$, Kumar $\mathbf{J}^{6}$, Gupta $\mathbf{J}^{7^{*}}$, Bano $\mathbf{R}^{8^{*}}$, \\ Dhunagana $\mathbf{H}^{9 *}$ and Sarthi $\mathbf{P}^{10}$ \\ ${ }^{1}$ Dr. Shah Mohammad Abbas Waseem, Assistant Professor, Department of Physiology, ${ }^{2}$ Dr. Ankita Kumari, \\ Audiologist and Speech Pathologist, Department of Multiple Disabilitie and Rehabilitation, ${ }^{3}$ Dr Shakuntala \\ Misra National Rehabilitation University Lucknow, ${ }^{4}$ Dr. Charu Singh, Professor Department of ENT, \\ ${ }^{5}$ Dr. Seema Singh, Professor Department of Physiology, ${ }^{6}$ Dr. Jitendra Kumar, Professor Department of \\ Physiology, HIMS Varanasi, ${ }^{7}$ Dr. Jaya Gupta, Senior Resident Department of ENT, ${ }^{8}$ Dr. Rubeena Bano, \\ Professor Department of Physiology, ${ }^{9}$ Dr. Homnath Dhunagana, Statistician cum Assistant Professor \\ Department of Community Medicine, ${ }^{10}$ Dr. Parth Sarthi, Lecturer Raajkiya Medical College Jalaun, *IIMS \& R, \\ Integral University, Lucknow, India.
}

Address for Correspondence: Dr. Shah Mohammad Abbas Waseem, Email: abbas14waseem5@gmail.com

\begin{abstract}
Background: Smoking, age, gender, socioeconomic class and education may contribute to the hearing loss. In this study hearing loss between smokers (current and ex) and non smokers was compared. Materials and Methods: 145 smokers [79 current (68 males, 11 females) and 66 ex smokers (60 males, 6 females)] and 145 non smokers (69 males, 76 females) were studied. Modified Kuppuswamy scale and smoking index were used. Hearing loss was assessed by Audiometry. $\mathrm{P}$ value of $<0.05$ (unpaired t test and chi square test) was taken as statistically significant. Result: Statistically significant and non significant differences were found between the mean age and educational status of current -ex smokers and smokers-non smokers respectively. Statistically significant and non significant differences were found between the socioeconomic status of smokers-non smokers and current -ex smokers respectively. Difference was significant between smoking index of current and ex smokers ( $\mathrm{p}=0.003$ ). 70.05\% males had hearing loss as compared to females $(49.46 \%)$. About $59.24 \%$ and $26.09 \%$ hearing loss cases belonged to low education and upper and upper middle social class respectively. $68 \%$ and $24.24 \%$ of moderate and severe smoking index were of professional to graduate educational status. $36.17 \%$ and $30.30 \%$ of moderate to severe smoking index belonged to upper and upper middle socioeconomic class. $73.91 \%$ were from low social classes. $47.59 \%$ non smokers and $25.51 \%$ smokers had no hearing loss. The severity of hearing loss was more in heavy smokers. Conclusion: Hearing loss associated with smoking was found to be more in male gender, advancing age, low socioeconomic and educational classes.
\end{abstract}

Key words: Smoking, Risk Factors in Hearing Loss, Smoking Severity, Association of Smoking with hearing loss, Audiometry

\section{Introduction}

There is a possible link between smoking and hearing impairment/ loss [1]. As per Meta Analysis conducted in Japan, 9 out of 15 observational studies have shown positive association between smoking and hearing loss [2]. Prevalence of smoking in the age group of 18-64 years is around $26.5 \%$ and $21.2 \%$ in males and females of same

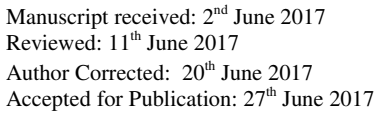

age group respectively [3]. Alarmingly there were 108 million male smokers in India in year 2015[4]. Prevalence of hearing loss in India is around 6.3\% [5]. It is estimated that smokers have $70 \%$ more risk of hearing impairment than non smokers [6]. In general smokers have 1.69 times more possibility of hearing loss as compared to non smokers [7]. The severity increases with increase in smoking. National Health Family Survey (NFHS-3) have reported $32.7 \%$ males and $1.4 \%$ females smoke 
between age groups 15-49 years, overall smoking increases with advancing age. As per a survey in India, it was found that prevalence of smoking was more in low socioeconomic groups as compared to middle and high income groups. Similarly smoking was more prevalent amongst low education/ illiterate/ primary/ informal education groups [8].

A study conducted in 2002 showed that the smokers between 20-35 years of age were at higher risk of hearing loss than those above 35 years of age. In the same study it was found that the prevalence of conductive deafness was more between age group 20-68 years who smoked. Conductive deafness was reported in $6.1 \%$ of current and past smokers, moreover smokers were twice more likely to suffer from mild sensorineural deafness as compared to non smokers. With increasing pack years of smoking and age the risk of hearing impairment increases [9]. In contrast to studies which have reported association between smoking and hearing loss there are studies which have reported no correlation between smoking and hearing loss [10].

Further there are studies which have shown that women who are current smokers are likely to have hearing loss than men who are current smokers [11]. Thus, there are conflicting reports on association of hearing loss with smoking. The possible mechanisms of smoking induced hearing loss may be attributed to multiple factors like hypoxia induced by reduction in blood supply to cochlea and spiral ganglion due to vasospasm and atherosclerotic damage; nicotine induced damage of neurotransmitter receptors ;smoking induced oxidative stress and changes in vascularity of auditory system[12-19]. Smoking is influenced by socioeconomic factors and education [20]. Study has shown positive association of demographic variables like smoking status, gender, education with diseases including hearing impairment [21]. The present study was undertaken to find association between smoking and hearing loss. It also assessed the hearing loss in various socioeconomic and education class and also in male and female gender.

\section{Materials and Methods}

Subjects were grouped into smokers (current smokers and ex smokers) and non smokers (who have / had never smoked) categories after taking proper history. A smoker was defined as an individual smoking at least one cigarette per day. An ex smoker was one who had quitted smoking for at least 6 months prior to study. Non smoker was one who had never smoked. Both males and females were recruited in the present study. On the basis of smoking index the subjects were classified into never smokers, mild/light (1-100), moderate (101-300) and heavy ( $\geq 301)$ smokers.

The hearing tests were done in a sound proof room in OPD of ENT by Trained Audiologist and Speech Pathologist. The subjects were asked about smoking history, hearing problems. Using the audiometric data, subjects with hearing loss were classified as with mild ( $>25$ decibel- $\leq 40$ decibel), moderate ( $>40$ decibel $-\leq 60$ decibel) and severe (>60 decibel).

Study Design: Cross sectional hospital based study.

Setting: Departments of Physiology and ENT, Integral Institute of Medical Science and Research, Lucknow. The Institutional Ethics Committee Clearance was obtained.

Inclusion Criteria: Subjects giving consent. Smokers, ex smokers and non smokers were included in the study.

Exclusion Criteria: Those having history of diabetes, hypertension, head trauma, any ear surgery, acute/ chronic infections of ear, deaf, history of any ototoxic medications, occupational noise exposure were excluded from the study.

Participants: ENT and other OPD's of IIMS\&R.

Data Source: Smoking history to classify subjects into smokers (current and ex) and non smokers. Subjects were asked about their educational, socioeconomic status and residence (rural and urban). Socioeconomic and education class was analyzed using Modified Kuppuswamy Scale [22]. Smoking index was calculated by multiplying the duration of smoking (years) with average number of sticks smoked per day [23]. The external ear problem was assessed using Diagnostic Otoscope by Welch Allyn. Tympanometry was performed to assess middle ear problem. Audiometry was performed using Hughson Westlake Method. The audiometer used was of MAICO Company (Model MAY2). 
Study Bias: Referral bias

Study Size: Total 290 subjects participated in the study. Study included 145 smokers (79 current and 66 ex smokers) and 145 non smokers.
Statistical Methods: The data was presented as mean \pm SD. Data was analysed using SPSS 21.0. Unpaired t test and chi square tests were used to analyze the data. $\mathrm{P}$ value $<0.05$ was taken as statistically significant.

\section{Results}

As per Table 1 out of 145 smokers, 79 were current smokers and 66 were ex smokers. In current smokers 68 were males and 11 were females. Out of 66 ex smokers 60 were males and 6 were females. In 145 non smokers, 69 were male and 76 were females. Statistically significant difference $(p=0.008)$ was found between the mean age of current $(47.48 \pm 13.71 \mathrm{yrs})$ and ex smokers ( $53.15 \pm 11.05 \mathrm{yrs})$. But the difference between smokers $(50.41$ $\pm 12.86 \mathrm{yrs})$ and non smokers $(46.51 \pm 11.83 \mathrm{yrs})$ was not significant $(\mathrm{p}=0.12)$. In current smokers 58/79 $(73.42 \%)$ belonged to high school to illiterate education class, whereas $26.58 \%$ (21/79) belonged to professional, graduate and intermediate education class. In ex smokers the figure was 50\% each i.e. (33/66). Overall in smokers i.e. current and ex smokers combined, 54/145(37.24\%) belonged to professional, graduate and intermediate education class and rest i.e. $91 / 145(62.76 \%)$ belonged to high school to illiterate class. In non smokers $94 / 145(64.14 \%$ ) belonged to high school to illiterate class and 51/145 i.e. $35.86 \%$ belonged to professional to intermediate education class. There was statistically significant difference in educational status of current and ex smokers $(\mathrm{p}<0.001)$ but difference was not significant between smokers and non smokers $(\mathrm{p}$ 0.123). Similar

Table-1: Differences between smokers (current and ex smokers) and smokers.

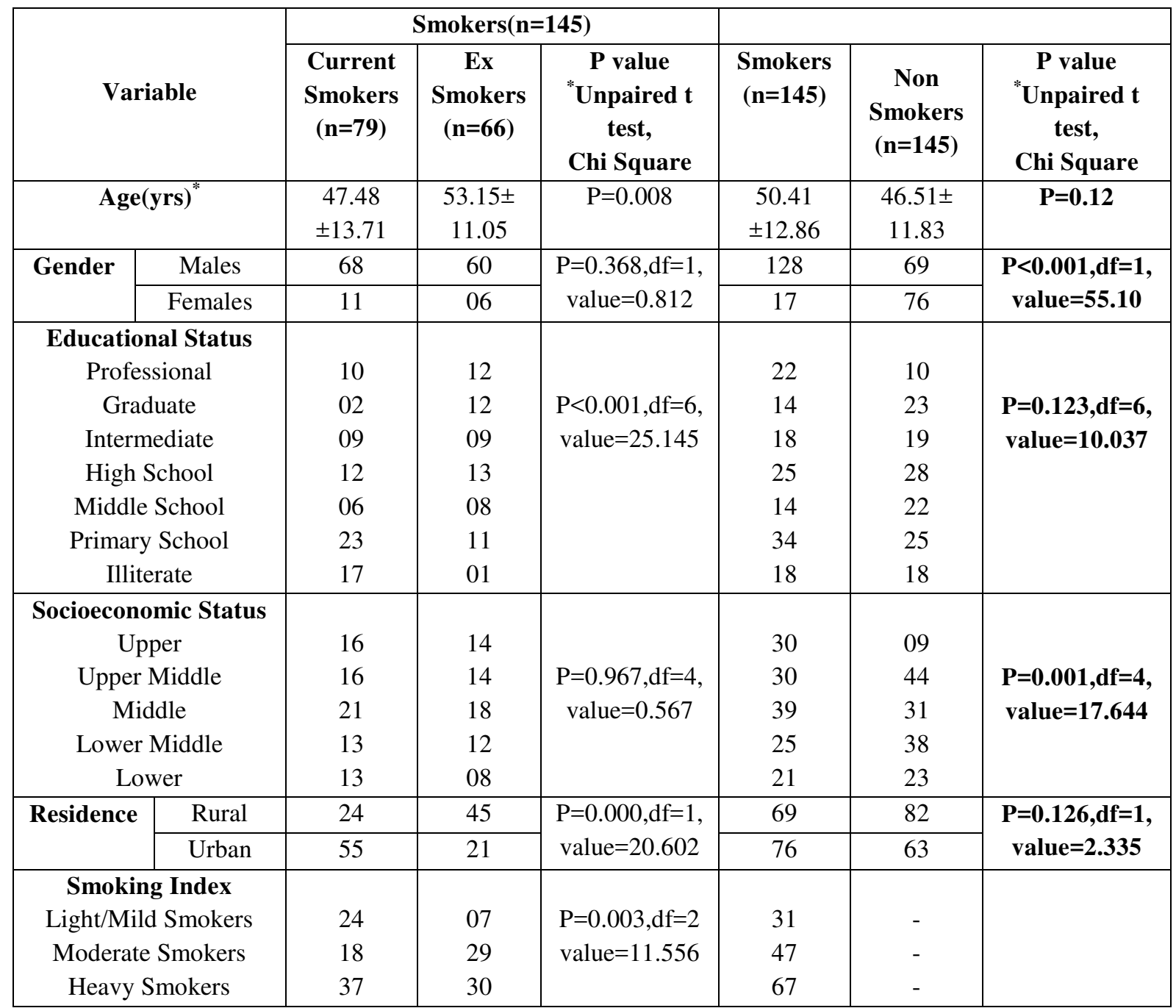


analysis of socioeconomic status found no significant difference between current and ex smokers (p 0.967) and significant difference between smokers and non smokers (p 0.001). In current and ex smokers subjects having rural and urban residence were 24,55 and 45,21 respectively (p significant at $<0.001$ ). In non smokers subjects belonging to rural and urban areas were 82 and 63 respectively. Statistically significant difference was found when smoking index of current and ex smokers were compared $(\mathrm{p}=0.003)$. Table 2 shows that hearing loss was present more in males as compared to females. $138 / 197$ i.e. $70.05 \%$ males and $49.46 \%$ females i.e. $46 / 93$ suffered from mild to severe hearing loss. Table 3 shows that out of total 184 subjects with hearing loss $40.76 \%$ belonged to professional to high school education class. This means Higher \% i.e. 59.24\% hearing loss cases were of low education class. $26.09 \%$ (48/184) cases with hearing loss belonged to upper and upper middle social class. Majority i.e. $73.91 \%$ were from low social classes. Table 4 shows that $21 / 47$ i.e. $44.68 \%$ and $16 / 66$ i.e. $24.24 \%$ of moderate and severe smoking index belonged to professional to graduate educational status. Similarly, $36.17 \%$ i.e. $17 / 47$ and $30.30 \%$ i.e. $20 / 66$ of moderate to severe smoking index belonged to upper and upper middle socioeconomic class. Table 5 shows that $69 / 145$ non smokers i.e. $47.59 \%$ suffered from no hearing loss. But on other hand $25.51 \%$ (37/145) smokers reported no hearing loss. Statistically significant differences were found when hearing loss were compared between smokers and non smokers $(\mathrm{p}=0.001)$ and current and ex smokers $(\mathrm{p}<0.0010)$. Table 6 shows that severity of hearing loss measured in decibel in each category of smoking index. The difference was statistically significant $(\mathrm{p}<0.001)$. The percentage of subjects with no loss of hearing was more in non smoker category.

Table-2: Hearing loss in males and females.

\begin{tabular}{|c|c|c|c|c|c|}
\hline \multirow[b]{2}{*}{ Gender } & \multicolumn{4}{|c|}{ Hearing Loss } & \multirow[t]{2}{*}{ Chi Square } \\
\hline & $\begin{array}{c}\text { Mild } \\
(>25-\leq 40 \mathrm{~dB})\end{array}$ & $\begin{array}{c}\text { Moderate } \\
(>40-\leq 60 \mathrm{~dB})\end{array}$ & $\begin{array}{c}\text { Severe } \\
(>60 \mathrm{~dB})\end{array}$ & No Loss & \\
\hline Male(n=197) & 63 & 42 & 33 & 59 & \multirow{2}{*}{$\begin{array}{r}P<0.001, d f=3, \\
\text { value }=25.752\end{array}$} \\
\hline $\operatorname{Female}(n=93)$ & 18 & 27 & 01 & 47 & \\
\hline
\end{tabular}

Table 3: Hearing Loss in Socioeconomic and Education Class.

\begin{tabular}{|c|c|c|c|c|c|}
\hline \multirow[t]{2}{*}{ Class } & \multicolumn{4}{|c|}{ Hearing Loss } & \multirow{2}{*}{$\begin{array}{c}\text { Chi Square } \\
\text { Test }\end{array}$} \\
\hline & Mild & Moderate & Severe & No Loss & \\
\hline \multicolumn{6}{|l|}{ Education } \\
\hline Professional & 11 & 02 & 02 & 17 & \multirow{8}{*}{$\begin{array}{c}\mathrm{P}<\mathbf{0 . 0 0 1}, \\
\mathrm{df}=\mathbf{1 8}, \\
\text { value }=\mathbf{1 1 2 . 5 4 5}\end{array}$} \\
\hline Intermediate & 20 & 02 & 00 & 15 & \\
\hline Graduate & 05 & 05 & 00 & 27 & \\
\hline High School & 15 & 10 & 03 & 25 & \\
\hline Middle School & 06 & 09 & 05 & 16 & \\
\hline Primary School & 16 & 26 & 12 & 05 & \\
\hline Illiterate & 08 & 15 & 12 & 01 & \\
\hline Total & 81 & 69 & 34 & 106 & \\
\hline \multicolumn{6}{|l|}{$\begin{array}{l}\text { Socio Economic } \\
\text { Class }\end{array}$} \\
\hline Upper & 14 & 03 & 02 & 20 & \multirow{6}{*}{$\begin{array}{c}P<0.001, \\
d f=12, \\
\text { value }=106.160\end{array}$} \\
\hline Upper Middle & 26 & 03 & 00 & 45 & \\
\hline Middle & 15 & 20 & 05 & 30 & \\
\hline Lower Middle & 19 & 22 & 12 & 10 & \\
\hline Lower & 07 & 21 & 15 & 01 & \\
\hline Total & 81 & 69 & 34 & 106 & \\
\hline
\end{tabular}


Original Research Article

Table 4: Number of subjects in smoking index categories from education and socioeconomic class

\begin{tabular}{|c|c|c|c|c|}
\hline \multirow[b]{2}{*}{ Class } & \multicolumn{3}{|c|}{ Smoking Index } & \multirow[t]{2}{*}{ Chi Square Test } \\
\hline & $\begin{array}{c}\text { Mild/Light } \\
(1-100)\end{array}$ & $\begin{array}{l}\text { Moderate } \\
(101-300)\end{array}$ & $\begin{array}{l}\text { Severe } \\
(\geq 301)\end{array}$ & \\
\hline \multicolumn{5}{|l|}{ Education } \\
\hline Professional & 10 & 04 & 08 & \multirow{8}{*}{$\begin{array}{c}P=0.002, \\
d f=12, \\
\text { value }=30.739\end{array}$} \\
\hline Intermediate & 02 & 06 & 06 & \\
\hline Graduate & 05 & 11 & 02 & \\
\hline High School & 05 & 03 & 17 & \\
\hline Middle School & 03 & 02 & 09 & \\
\hline Primary School & 04 & 15 & 15 & \\
\hline Illiterate & 02 & 06 & 10 & \\
\hline Total & 31 & 47 & 66 & \\
\hline \multicolumn{5}{|c|}{ Socio Economic Class } \\
\hline Upper & 09 & 07 & 14 & \multirow{6}{*}{$\begin{array}{c}P=0.001, \\
d f=8, \\
\text { value }=25.165\end{array}$} \\
\hline Upper Middle & 13 & 10 & 06 & \\
\hline Middle & 07 & 14 & 18 & \\
\hline Lower Middle & 00 & 12 & 13 & \\
\hline Lower & 02 & 04 & 15 & \\
\hline Total & 31 & 47 & 66 & \\
\hline
\end{tabular}

Table-5: Smoking status and hearing loss.

\begin{tabular}{|c|c|c|c|c|c|}
\hline \multirow{2}{*}{ Smoking status } & \multicolumn{4}{|c|}{ Hearing loss } & \multirow{2}{*}{ Chi Square test } \\
\cline { 2 - 5 } & Mild & Moderate & Severe & No Loss & \\
\hline Smoker(n=145) & 45 & 43 & 20 & 37 & $\mathrm{P}=0.001, \mathrm{df}=3$,value $=1$ \\
\cline { 2 - 5 } Non Smoker(n=145) & 36 & 26 & 14 & 69 & 5.908 \\
\hline Current Smoker(n=79) & 24 & 19 & 05 & 31 & $\mathrm{P}<0.001, \mathrm{df}=3$,value $=2$ \\
\cline { 1 - 4 } & 21 & 24 & 15 & 06 & 1.682 \\
\hline
\end{tabular}

Table-6: Hearing loss on the basis of severity of smoking.

\begin{tabular}{|c|c|c|c|c|c|}
\hline \multirow[t]{2}{*}{ Smoking Severity } & \multicolumn{4}{|c|}{ Severity of hearing loss } & \multirow{2}{*}{$\begin{array}{c}\text { Chi Square } \\
\text { Test }\end{array}$} \\
\hline & Mild & Moderate & Severe & No Loss & \\
\hline Non Smoker(n=145) & 36 & 26 & 14 & 69 & \multirow{4}{*}{$\begin{array}{l}\mathrm{P}=0.000, \mathrm{df}=9, \\
\text { value }=60.642\end{array}$} \\
\hline Light/mild smoker(n=24) & 12 & 00 & 00 & 12 & \\
\hline Moderate Smoker(n=47) & 17 & 19 & 00 & 11 & \\
\hline Heavy Smoker(n=74) & 16 & 24 & 20 & 14 & \\
\hline
\end{tabular}

\section{Discussion}

Tobacco use has now reached the scales of epidemic. It is estimated that there are 1.1 billion consumers of smoked tobacco worldwide. The use of tobacco and tobacco related products is increasing worldwide specially in developing countries. $80 \%$ of smokers belong to low and middle income group. Owing to tobacco smoke environmental pollution and menace of second hand smoking is on rise [24]. Cigarette smoke contains more than 6000 Chemical Compounds, and both Free Radicals and Oxidants are present in abundance [25]. Direct and indirect inhalation of tobacco smoke has deleterious effects on heath. The prevalence of hearing loss is reportedly more in smokers as compared to non smokers [26]. Noxious stimuli lead to excess production of free 
radicals in cochlea, which, in turn, affects hearing. In fact, cochlea is highly sensitive to nicotine, which disrupts auditory function pathway by interfering with cholinergic transmission and processing of auditory impulses [27, 28].

Male gender and increasing age have been identified as risk factors for hearing impairment [29]. In our study we have found that number of male subjects with hearing loss was more as compared to females. The results may be attributed to multiple reasons. It has been observed that Men are more exposed to noise at work place, are more prone to smoking and other risk factors implicated in hearing impairment like hypertension [30].

In the present study we have found that mean age of the smokers was more than the non smokers. On the other hand hearing loss in smokers was more than that in non smokers. We also found that severity of hearing loss was more in smokers with higher smoking index. The results can be explained on the basis of earlier studies. Prasad BK et al found that with increase in smoking severity and pack years hearing impairment was more [31]. Paschoal CP et al studied the deleterious effects of smoking on hearing and concluded that harmful effects of smoking have direct relation with number of cigarettes smoked and indirect relation with age of the commencement of smoking [32]. Interestingly in our study we have found that non smokers were also having varying degree of hearing loss. It may be attributed to various reasons. Smokers are twice at risk of hearing loss as compared to non smokers. Although we have not studied the other causes of hearing loss but studies have shown that people exposed to second hand smoke are 1.94 times more likely to suffer from hearing loss [33]. Second Hand Smoke or environmental tobacco smoke impairs hearing by affecting outer hair cells [34]. Lalwani AK et al gave an interesting observation that hearing loss in adults may commence at an early age and also effects those who are exposed passively to smoking [35]. Age related hearing loss can be attributed to multiple factors like hypoxia, atherosclerosis, oxidative stress, dysfunction of mitochondrion and programmed suicidal death of inner ear cell [36].

In our study we have found that in ex smokers 60 subjects were having hearing loss as compared to 45 in current smokers. This means that ex smokers were having more hearing loss. This is in contrast with the study done earlier which have shown that current smokers are 1.73 times more likely to have hearing loss as non-smokers [37]. In our study also we have found higher number of smoker subjects with hearing loss than non smokers. But the possible explanation of ex smokers having more hearing loss than current smokers in our study could be attributed to the fact that in our study mean age of ex smokers was more than current smokers. Fabry DA et al found that in never and former smokers advancing age was a risk factor for hearing loss [38]. In our study out of total 184 subjects with hearing loss, $40.76 \%$ belonged to professional to high school education class. This means Higher \% i.e. 59.24\% hearing loss cases were of low education class. $26.09 \%$ (48/184) cases with hearing loss belonged to upper and upper middle social class. Majority i.e. 73.91\% were from low social classes. Thus, hearing loss was more in low education and socioeconomic classes. Cruickshanks KJ et al found that odds of hearing impairment were lower with higher education and income [39]. In our study $44.68 \%$ and $24.24 \%$ of subjects with moderate and severe smoking index belonged to professional to graduate educational status. Similarly, $36.17 \%$ and $30.30 \%$ of moderate to severe smoking index subjects belonged to upper and upper middle socioeconomic class.

Interestingly, as written earlier that higher percentage of subjects with hearing loss belonged to low education and social class. Thus, it is inferred indirectly that hearing loss is more prevalent in low education and income class. The possible explanation could be that people with higher education are expected to be less exposed to occupational noise and thus are relatively protected from hearing impairment [40]. Pampel FC found that socioeconomic status and education have relation with smoking and its harmful effects. Income and education influence the smoking habits of individual. The people with low education usually have difference in awareness and perception of harmful effects of smoking as compared to those with higher education. Similarly, smoking in low socio economic class is often influenced by buying capacity and use of smoking as de stressor [41]. Studies have shown that low education, low income, male gender, urban residence are risk factors for hearing impairment [42-44]. 


\section{Conclusion}

The subjects with more severity of smoking index have more hearing loss as compared to non smokers. There are various factors like gender, residence, socioeconomic and education which influence the harmful effects of smoking on auditory mechanism and effect hearing. The overall results can be attributed to knowledge, awareness and attitude towards the harmful effects of smoking on health. The results of study show that smoking does influence the hearing. There is a need to make the public aware about the harmful effects of smoking. Awareness campaigns are need of the hour. The results are showing that there is widespread distribution of smoking (current or ex) across every socioeconomic and education class. Lesser percentage of smoking in females may not be indicative of lesser problem of smoking in females. It may be due to low acceptance of smoking by females.

Limitations: The present study was not done to identify the conductive/sensorineural or mixed hearing loss in smokers and non smokers. But identification of pattern of hearing loss will yield better results. The study if done on large scale will yield a better result. The identification of risk factors, estimating hearing loss in both smoked and smokeless tobacco users, considering occupational/ workplace exposure to noise and blood chemistry will yield better results.

Acknowledgement: Authors are thankful to the participants in the study and wish them a happy and healthy life. Also wish to thank supporting staff who have helped directly or indirectly contributed towards the completion of study.

\section{Funding: Nil, Conflict of interest: None Permission of IRB: Yes}

\section{References}

1. Rogha M, Hashemi M, Askari N, Abtahi SH, Sepehrnejad M, Nilforoush MH. Cigarette smoking effect on human cochlea responses. Adv Biomed Res. 2015; 4:148. doi: 10.4103/2277-9175.161575. eCollection 2015.

2. Kyoko Nomura, Mutsuhiro Nakao, Takeshi Morimoto. Effect of smoking on hearing loss: quality assessment and meta-analysis. Preventive
Medicine. 2005; 40 (2):138-14. DOI:10.1016/j. ypmed. 2004.05.011

3. Carper $\mathrm{K}$ and Machlin SR. Variations in Smoking by Selected Demographic, Socioeconomic, Insurance, and Health Characteristics, United States, 2003. Statistical Brief \#101. October 2005. Agency for Healthcare Research and Quality Rockville,Md.http:// meps. ahrq.gov/mepsweb/datafiles/publications/st101/ stat101. pdf.

4. Mishra S, Joseph RA, Gupta PC, Pezzack B, Ram F, Sinha DN, Dikshit R, Patra J, Jha P. Trends in bidi and cigarette smoking in India from 1998 to 2015, by age, gender and education. BMJ Glob Health. 2016 Apr 6;1(1):e000005. doi: 10.1136/ bmjgh-2015-000005. eCollection 2016 Apr.

5. Guleria TC,Mohindroo S,Mohindroo SK and Azad RK.Prevalaence and etiology of hearing imapairment in urban areas of Shimla, Himachal Pradesh, India: a cross sectional observational study. International Journal of Research in Medical Sciences. 2017; 5(4):1252-1255.

6. Panigrahi R and Maheshwari A. Prevalence of Hearing Loss in Adolescet Smokers. Journal of Evolution of Medical and Dental Sciences.2015; 4 (48):8298-8303.

7. Gaur K, Kasliwal N and Gupta R. Association of smoking or tobacco use with ear diseases among men: a retrospective study. Tobacco Induced Diseases 201210:4.DOI: 10.1186/1617-9625-10-4.

8. National Family Health Survey (NFHS-3) India; Vol 1, Table 13.10, Page 433 (2005-2006). MOHFW/GOI.

9. Katbamna B. Effects of Smoking on Auditory System. Audiology Online. available online at www.audiologyonline.com/articles/effectssmoking-on-auditory-system-899.

10. Kumar A, Gulati R, Singhal S, Hasan A, Khan A. The Effect of Smoking on the Hearing Status-A Hospital Based Study. Journal of Clinical and Diagnostic Research: JCDR. 2013; 7(2):210-214. doi:10.7860/JCDR/2013/4968.2730. 
11. Kobayashi $\mathrm{Y}$, Tamiya N, Moriyama $\mathrm{Y}$ and Nishi A. Triple Difficulties in Japanese Women with Hearing Loss: Marriage, Smoking, and Mental Health Issues. PLOS One. 2015; 10(2): e011 6648 .

12. Cruickshanks KJ, Klein R, Klein BE, Wiley TL, Nondahl DM, Tweed TS. Cigarette smoking and hearing loss: the epidemiology of hearing loss study. JAMA. 1998 Jun 3; 279 (21): 1715-9.

13. Nondhal DM, Cruickshanks KJ, Dalton DS, Schubert CR, Klein BEK, Klein R and Tweed TS. Serum Cotinine Level and Incident Hearing Loss: A Case-Control Study.Archives of Otolaryngology, Head and Neck Surgery. 2004; 130(11): 12601264.

14. Sung JH, Chang SS, Lee CR, Yoo CI, LeeH, Yanghokim and Lee J. Relationship of cigarette smoking and hearing loss in workers exposed to occupational noise. Annals of Occupational and Environmental Medicine.2013;25:8. DOI: 10.1186/ 2052-4374-25-8.

15. Ferrite S, Santana V. Joint effects of smoking, noise exposure and age on hearing loss. Occup Med (Lond). 2005 Jan;55(1):48-53.

16. Liang K, Poytress BS, Chen Y, Leslie FM, Weinberger NM, Metherate R. Neonatal nicotine exposure impairs nicotinic enhancement of central auditory processing and auditory learning in adult rats. Eur J Neurosci. 2006 Aug;24(3):857-66. Epub 2006 Jul 18

17. Lustig LR. Nicotinic acetylcholine receptor structure and function in the efferent auditory system. The Anatomical Record. Part A. Discoveries in Molecular, Cellular, and Evolutionary Biology. 2006; 288(4):424-434.

18. Morley BJ. Nicotinic cholinergic intercellular communication: implications for the developing auditory system. Hear Res.2005Aug; 206 (1-2): 74-88.

19. Siegelaub AB, Friedman GD, Adour K, Seltzer CC. Hearing loss in adults: relation to age, sex, exposure to loud noise, and cigarette smoking. Arch Environ Health. 1974 Aug;29(2):107-9.
20. Yun WJ, Rhee JA,Kim SA,Kweon SS,Lee YH, Ryu SY, Park SW, Kim DH and Shin MH. Household and area income levels are associated with smoking status in the Korean adult population. BMC Public Health. 2015; 15:39.DOI: 10.1186/ s12889-015-1365-6.

21. Zin T, Myint T, Naing DKS, Htay K, Wynn AA, SabaiAung T, Musleh ASB and Robinson F. A study on health-related quality of life and comorbidity among elderly population in rural Sabah, Malaysia. South East Asia Journal of Public Health. 2015; 5(2):35-42.

22. Shaikh Z, Pathak R. Revised Kuppuswamy and B G Prasad socio-economic scales for 2016. International Journal of Community Med Public Health. 2017; 4(4):997-9.

23. Singh N, Aggarwal AN, Gupta D, Behera D, Jindal SK. Quantified smoking status and nonsmall cell lung cancer stage at presentation: analysis of a North Indian cohort and a systematic review of literature. Journal of Thoracic Disease. 2012; 4(5):474-484.

24. WHO. Available online at www.who.int/topics/ tobacco/en.

25. Waseem SM, Mobarak MH, Islam N, Ahmad Z. Comparative study of pulmonary functions and oxidative stress in smokers and non-smokers. Indian J Physiol Pharmacol. 2012 Oct-Dec;56 (4):345-52.

26. Nair PG, Jestina JJ, Unnikrishnan $H$ and Chandrahasan H. Effects of Cigarette Smoking on Auditory Function. Research in Otolaryngology. 2016; 5(1):9-15.

27. Shabina, Kabali B, Kapali BSC. Evaluation of Brainstem Auditory Evoked Potential in Chronic Smokers. Indian Journal of Innovations and Developments. 2012; 1(8):15-17.

28. Henderson D, Bielefeld EC, Harris KC, Hu BH. The role of oxidative stress in noise-induced hearing loss. Ear Hear. 2006 Feb;27(1):1-19.

29. Ramma L and Sebothoma B. The prevalence of hearing impairment within the Cape Town Metropolitan area. South African Journal of 
Communication Disorders .2016; 63(1), a105. http: // dx.doi. org/10.4102/sajcd.v63i1.105.

30. Kanjikar S, Doddamani A, Malige R and Reddy N. Audiometric analysis of type and degree of hearing impairment and its demographic correlation: A retrospective study. Journal of Advanced Clinical \& Research Insights .2015; 2(5), 189-192.

31. Prasad BK and Nayak Sunanda V. Study of of Effect of Smoking on Auditory Acuity. Indian Journal of Public Health Research \& Development. 2013; 4(4): 162-167.

32. Paschoal CP, Azevedo MF. Cigarette smoking as a risk factor for auditory problems. Braz $\mathrm{J}$ Otorhinolaryngol. 2009 Nov-Dec;75(6):893-902.

33. Monahan RA and Sieminski LR Hearing LossUndiagnosed and Untreated. Today's Geriatric Medicine. 2014; 7(3):14.

34. Chang J, Ryou M, Jun HJ, Hwang SY, Song JJ and Chae SW. Effect of Cigarette Smoking and Passive Smoking on Hearing Impairment: Data from a Population BasedStudy.PLOSOne.2016; 11(1).e0146608.https://doi.org/10.1371/journal.pon e.0146608.

35. Lalwani AK, Liu YH, Weitzman M. Secondhand smoke and sensorineural hearing loss in adolescents. Arch Otolaryngol Head Neck Surg. 2011 Jul;137(7):655-62. doi: 10.1001/archoto. 2011. 109

36. Lin TY, Wu LW, Kao TW, Wu CJ, Yang HF, Peng TC, Lin YJ and Chen WL. Secondhand Smoke is Associated with Hearing Threshold Shifts in Obese Adults. Scientific Reports. 2016; 6, 33071; doi: 10.1038/srep33071.

37. Zir EE,Doumit M, and Chahine R. Nicotine Addiction and Hearing Loss in Young Subjects
From Beirut, Lebanon.Int J High Risk Behav Addict.2016;5(4): 31522.

38. Fabry DA, Davila EP, Arheart KL, Serdar B, Dietz NA, Bandiera FC, Lee DJ. Secondhand smoke exposure and the risk of hearing loss. Tob Control. 2011 Jan;20(1):82-5. doi: 10.1136/tc.2010. 035832. Epub 2010 Nov 15.

39. Cruickshanks KJ, Dhar S, Dinces E, Fifer RC, Gonzalez F 2nd, Heiss G, Hoffman HJ, Lee DJ, Newhoff M, Tocci L, Torre P 3rd, Tweed TS. Hearing Impairment Prevalence and Associated Risk Factors in the Hispanic Community Health Study/Study of Latinos. JAMA Otolaryngol Head Neck Surg. 2015 Jul; 141(7):641-8. doi: 10.1001/ jamaoto.2015.0889.

40. Rigters SC, Metselaar $\mathrm{M}$ Wieringa $\mathrm{MH}$, de Jong RJB, Hofman A and Goedegebure A. Contributing Determinants to Hearing Loss in Elderly Men and Women: Results from the Population-Based Rotterdam Study. Audiol Neurotol. 2016; 21(suppl 1):10-15.

41. Pampel FC. Socioeconomic Distinction, Cultural Tastes, and Cigarette Smoking. Social science quarterly. 2006; 87(1):19-35. doi:10.1111/j. 0038-4941.2006.00366.x.

42. Kim JS. Prevalence and factors associated with hearing loss and hearing aid use in korean elders. Iran J Public Health. 2015 Mar;44(3):308-17.

43. Yun C, Wang Z, Gao J, He P, Guo C, Chen G and Zheng X. Prevalence and Social Risk Factors for Hearing Impairment in Chinese Children- A National Survey. International Journal of Environmental Research and Public Health.2017, 14 (1), 88; doi: 10.3390/ijerph14010088.

44. Emmett SD, Francis HW. The socioeconomic impact of hearing loss in U.S. adults.Otol Neurotol. 2015 Mar; 36(3):545-50. doi: 10.1097/ MAO. 0000000000000562 .

\section{How to cite this article?}

Waseem S.M.A, Kumari A, Misra S, Singh C, Singh S, Kumar J, Gupta J, Bano R, Dhunagana H and Sarthi P. Association between smoking and hearing status: a comparative study between smokers and non - smokers. Int J Med Res Rev 2017;5(06):576-584. doi:10.17511/ijmrr. 2017.i06.06. 